\title{
14 \\ DOMESTIKASI TEKNOLOGI INFORMASI DAN KOMUNIKASI KELUARGA MUSLIM DI KAMPUNG CYBER SURABAYA
}

\author{
Moch. Choirul Arif', Ries Dyah Fitriyah² \\ Fakultas Dakwah dan Komunikasi UIN Sunan Ampel Surabaya \\ Choirul.Arief@uinsby.ac.id ${ }^{1}$, rusydalama3@gmail.com $^{2}$
}

\begin{abstract}
The aim of the research is to explain; first, the basic argument for household muslims to domesticate information and communication technology. Second, the process of domestication of information technology. The third implication of the domestication of technology and information. This study used descriptive qualitative method with phenomenological approach. The goal is to understand the meaning behind the action naturally. The results of this study are: First, domestication of the information and communication technology rests on reasoning awareness, that leads to understanding the meaning and function of information and communication technology for them (Purposeful actions). Second.The existence of kampoeng cyber as instrument of the process of domestication of information and communication technology. Was apparently able to bring parents and children together in cultural negotiation space. The result is a process of aproriation, objectification, incorporation and conversion which accelerate the domestication of information and communication technology. Third, Moslem family awareness of the positive and negative impact that the process of domestication of information and communication technology influences their religious and social interactions. Therefore, the Cyber Kampoeng developed is used a medium of the construction awareness and values inheritance in the next generation.
\end{abstract}

Keywords: Domestication, social construction, moslem family.

\begin{abstract}
Abstrak: Ada tiga persoalan dalam penelitian ini. Pertama, dasar argumentasi keluarga muslim mendomestikasi informasi dan komunikasi. Kedua, proses domestikasi teknologi informasi. Ketiga implikasi domestikasi teknologi dan informasi. Penelitian ini menggunakan metode deskriptif kualitatif dengan pendekatan fenomenologi. Tujuannya adalah memahami makna dibalik tindakan secara alamiah. Hasil penelitian ini adalah: Pertama, Domestikasi teknologi informasi dan komunikasi bertumpu nalar kesadaran yang berujung pada pemahaman makna dan fungsi teknologi informasi dan komunikasi bagi mereka (tindakan bertujuan). Kedua, Keberadaan kampung siber sebagai instrumen proses domestikasi teknologi dan informasi, ternyata mampu mempertemukan orang tua dengan anak dalam ruang negosiasi budaya. Hasilnya adalah proses aproriasi, obyektifikasi, inkorporasi dan koversi yang mempercepat domestikasi teknologi informasi dan komunikasi. Ketiga, keluarga muslim sadar terhadap dampak positif dan negatif bahwa proses domestikasi teknologi informasi dan komunikasi mempengaruhi keberagamaan dan interaksi sosialnya. Karena itu kampung siber dijadikan sebagai media konstruksi kesadaran dan pewarisan nilai pada generasi berikutnya.
\end{abstract}

Kata Kunci: Domestikasi, konstruksi sosial, rumah tangga muslim. 


\section{A. Pendahuluan}

Saat ini teknologi informasi dan komunikasi telah menjadi elemen penting dalam kehidupan manusia. Kehadirannya sejak awal dimaksudkan membantu manusia dalam mencapai tujuan hidup. Manusia lebih mudah dan lebih cepat dalam menjalankan aktifitasnya. Dalam konteks ini, sulit bagi manusia untuk menafikan apalagi menolak kehadiran teknologi dan informasi.

Begitu vitalnya teknologi, hingga hidup manusia merasa sulit bergerak jika tidak bersentuhan dengan teknologi. Manusiapun menjadi bergantung dan tergantung dengan teknologi. Dalam padangan Marshall MacLuhan kondisi itu menunjukkan bentuk lain dari "ketidakberdayaan" manusia terhadap teknologi (determinism technology theory). Teknologi informasi dan komunikasi telah mengambil fungsi sosial manusia. Masyarakat yang pada awalnya guyup, intensif berinteraksi dan berkomunikasi secara face to face menjadi "menjauh", lantaran mereka telah menemukan "teman dan keramaian" dalam kesendirian. Dengan pola demikian manusia dipaksa untuk melihat, mendengar, membaca serta menginternalisasi nilai-nilai yang dikonstruksikan oleh teknologi informasi dan komunikasi.

Teknologi informasi dan komunikasi memang menawarkan berbagai kemudahan, kecanggihan dan keluarbiasaan bahkan dalam perkembangannya juga menawarkan kenyamanan bagi penggunannya (sparkling pleasure), namun sifatnya yang ambigu, ${ }^{343}$ kompleks $^{344}$ dan rumit seringkali memberikan konsekuensi-konsekuensi yang berujung pada menghasilkan persoalan baru dan sisa persoalan bagi manusia itu sendiri. Misalnya dampak ekologis teknologi, memudarnya peran manusia karena telah tergantikan hingga memudarnya nilai-nilai kultural dari sebuah komunitas. Meski demikian, karena teknologi telah menjadi elemen katalisator dari manusia modern dalam menopang aktifitasnya, maka teknologi menjadi instrumen yang sulit untuk ditinggalkan (determinisme).

Riset Nielson Indonesia yang dirilis tanggal 6 Maret 2013 bertajuk "Uncommon sense of The Consumer" menunjukkan bahwa kebutuhan teknologi informasi dan komunikasi kian waktu mengalami peningkatan penggunaan. Hal itu dapat dilihat data sebagai berikut, pembaca majalah naik dari 5\% menjadi 7\% dengan durasi konsumsi naik 44 menit. Pembaca tabloid tumbuh menjadi 8\%, Surat Kabar 13\% dengan peningkatan konsumsi waktu 31 menit dan 39 menit. Penggunaan internet naik menjadi 30\% seiring dengan perubahan gaya hidup masyarakat Indonesia yang mengarah pada gaya hidup digital. Bahkan menurut CNN Indonesia ada pertumbuhan luar biasa pengguna internet di Indonesia di tahun 2013 sebesar 71, 9 juta menjadi 88, 1 juta di tahun 2014. Ini artinya ada pertumbuhan 34, $9 \%$ dari total penduduk Indonesia ${ }^{345}$

Peningkatan penggunaan teknologi informasi dan komunikasi tersebut menunjukkan bahwa masyarakat semakin memerlukannya meski menyadari bahwa sifat ambigu dan kompleksitas teknologi dapat berdampak bagi perubahan dirinya. Terkait dengan itu, beberapa pihak telah berupaya menjadikan teknologi sebagai instrumen "pendamping hidup" manusia. Pemerintah Indonesia misalnya dengan UU nomer 6 tahun 2014 tentang desa melakukan gerakan "internet masuk desa”, yang digunakan untuk pengembangan potensi desa, pelatihan SDM Desa Melek TIK dan sebagainya dengan harapan mengakselerasi proses pembangunan agar lebih maju dan mengejar ketertinggalannya. Demikian pula yang terjadi di level komunitas cukup banyak ditemui inisiatif mengenalkan dan menginstalasi rumah dan kampungnya dengan teknologi informasi dan

\footnotetext{
343 Sifat ambigu ini memberikan makna bahwa teknologi dapat ditarik kemana-kemana, bergantung siapa yang menggunakan dan untuk kepentingan apa, memiliki dampak positif tapi juga memiliki dampak negatif. Sehingga bisa saja keberadaan teknologi informasi dan komunikasi memberikan manfaat yang besar bagi kehidupan manusia, tapi bisa juga di sisi lain memberikan resiko yang tidak kecil bagi keberlangsungan kehidupan manusia dan kemanusiaan.

${ }^{344}$ Kompleksitas teknologi informasi dan komunikasi bersangkut paut dengan dua sisi, yaitu hardware dan software. Hardware berkaitan dengan komponen pembentuk teknologi yang bersifat teknis dan mekanis. Sementara software menyangkut keahlian yang diperlukan oleh seseorang dalam mengoperasikan teknologi itu.

345 CNN Indonesia, “2014, Pengguna Internet Indonesia capai 88, 1 juta” Kamis/26/2015 (online) www.cnnindonesia.com diakses tanggal 1 maret 2016.
} 
komunikasi, dengan maksud menjalin kebersamaan, menumbuhkan rasa memiliki dan cinta terhadap komunitasnya (kampung, perumahan) hingga menghidupkan ekonomi masyarakat berbasis kearifan lokal yang dimediasi teknologi informasi dan komunikasi.

Kampung Jojoran 3B di kelurahan Mojo Kecamatan Gubeng Surabaya merupakan kampung yang "didesain" menjadi kampung siber. Kampung yang menjadikan teknologi informasi dan komunikasi sebagai instrumen pelengkap kebutuhan warganya dalam menjalankan aktifitas. Mulai dari aktifitas keseharian hingga aktifitas ekonomi yang berdampak peningkatan kesejahteraan. Terjadinya kampung Jojoran 3B ini memberikan asumsi bahwa ada proses apropriasi yang dilakukan masyarakat Jojoran (rumah tangga muslim) dalam mendomestikasi teknologi informasi dan komunikasi.

\section{B. Metode Penelitian}

Kajian ini menggunakan menggunakan pendekatan fenomenologi, dengan harapan mampu memahami (a) konstruksi budaya rumah tangga muslim dalam memaknai teknologi dan informasi (b) appropriasi rumah tangga muslim terhadap teknologi informasi dan komunikasi. Untuk memperdalam pendekatan itu, maka metode kualitatif deskriptif dirasa tepat untuk memaparkan fenomena tersebut yang memanfaatkan instrumen pengumpulan data seperti wawancara mendalam, observasi partisipan, analisis dokumen dan focus group discussion (fgd). Data yang terkumpul melalui instrumen tersebut dianalisis menggunakan model alir Miles dan Huberman ${ }^{346}$ yang bertumpu pada proses pengumpulan data, reduksi data, penyajian data dan verifikasi data yang berjalan secara simultan. Melalui tehnik ini diharapkan tersaji data yang validitasnya terjaga.

\section{Hasil dan Pembahasan}

\section{Kampung Siber: Konstruksi kultural warga Jojoran 3B}

Sejak awal berdirinya, kampung siber di wilayah Jojoran 3B merupakan kreasi anak muda yang ingin berbuat lebih untuk kampungnya dengan cara memanfaatkan program internet gratis bagi RT dan RW kota Surabaya. Berbekal kemampuan teknis komputer dan mengoperasikan internet, dibuatlah sebuah blog yang berisi segala hal yang terkait dengan keberadaan kampung Jojoran 3B. Mulai dari mencantumkan struktur dan nama pengurus RT, PKK, biografi pengurus, kegiatan warga, laporan keuangan pengurus RT hingga usaha ekonomi yang dimiliki warga. Melalui blog tersebut diharapkan warga masyarakat Jojoran 3B mengetahui dan memahami kerja pengurus kampung dan aktifitas warga kampung yang pada akhirnya diharapkan juga tumbuah kesadaran dan partispasi warga terhadap aktifitas di kampung.

Meski tidak gampang mewujudkannya karena muncul berbagai kekhawatiran dari orang tua (digital immigrant) terhadap dampak yang ditimbulkan dari pengggunaan internet itu, tetapi akhirnya program kampung yang dikelola anak muda (digital native) tetap jalan dan berlangsung dengan lancar. Kondisi ini secara asumtif dapat disebabkan oleh beberapa hal: (a) lahirnya program kampung siber merupakan wujud kreatifitas yang nyata dari anak muda di Jojoran 3B dalam menyambut program pemerintah kota Surabaya terkait dengan internet gratis selama 6 bulan. Artinya, jika program internet gratis ini tidak disambut dan dimanfaatkan, maka akan terjadi kesiasian. Padahal program internet gratis mau tidak mau harus diterima oleh pengurus RT di wilayah Surabaya, (b) ada kesepakatan yang dihasilkan dari negosiasi anak muda (digital native) dengan orang tua (digital immigrant) terkait dengan program internet gratis dari pemerintah kota Surabaya, yang tidak hanya sekedar memanfaatkan internet, tetapi harus mampu memberikan kontribusi bagi pengembangan kampung Jojoran 3B, (c) keinginan untuk mengreasikan image baru bagi kampung Jojoran yang selama ini dikenal sebagai kampung preman Surabaya, menjadi kampung yang kreatif, cerdas dan berprestasi. Keinginan itu kemudian mewujud dalam sebuah blog yang diberi nama kampung siber Jojoran 3B

346 A. Michael Matthew Hubberman dan Miles B. Analisis Data Kualitatif. Terj. Tjejep (Jakarta:UI Press, 1992), 20 
Terlepas apakah konsep kampung siber merupakan adopsi dari program sejenis yang ada di kota Yogyakarta dan kota-kota di Indonesia, namun usaha yang dilakukan oleh anak muda dan orang tua di Jojoran 3B merupakan langkah kreatif. Paling tidak program itu memberikan dampak yang luar biasa bagi dinamika masyarakat di wilayah Jojoran, dan paling penting adalah muncul perubahan image terhadap kampung di wilayah Jojoran sebagai kampung modern dan berprestasi. Image itu bukan mimpi, namun terwujud dengan nyata. Program kampung siber yang digagas anak muda Jojoran 3B ternyata memberikan inspirasi bagi kampung-kampung sekitarnya untuk melakukan hal yang sama, namun berbentuk lain, misalnya kampung KAMANDANU (kampung aman, indah dan terpadu), dan kampung BOLA. Selain itu keberadaan blog kampung siber yang menyajikan berbagai informasi telah memberikan rasa kepercayaan warga terhadap pengurus RT, dan menumbuhkan partisipasi warga sekitar untuk mengikuti berbagai even kota, yang pada akhirnya melahirkan sebuah prestasi bagi kampung Jojoran 3B.

Untuk mempermudah proses lahirnya kampung siber di Jojoran 3B, dapat diskemakan sebagai berikut:

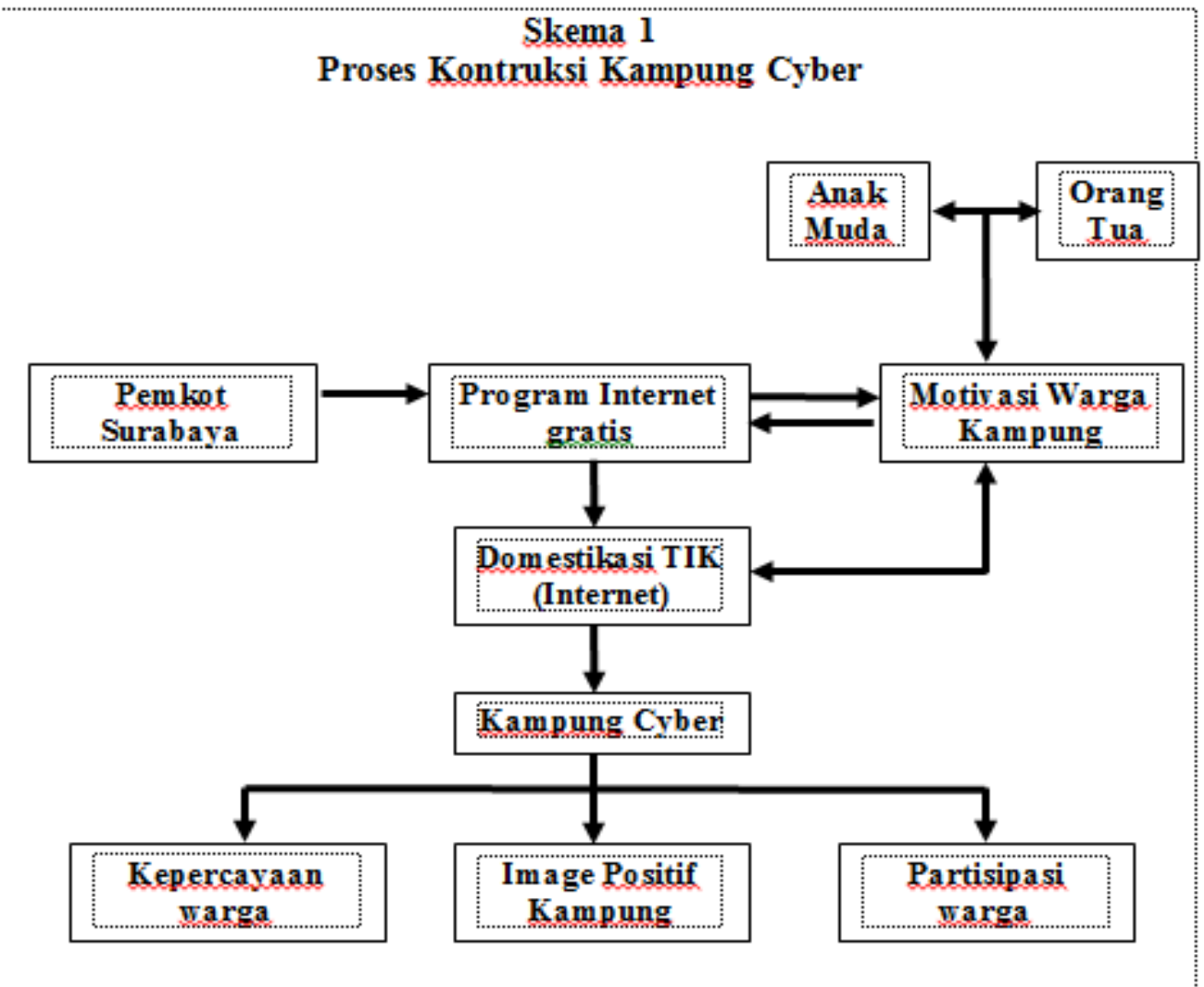

Mencermati skema tersebut tampak bahwa kampung siber dikonstruksi secara terencana oleh warga Jojoran 3B. Melalui serangkaian negosiasi antara anak muda dan orang tua menghasilkan sebuah motivasi tersendiri dalam menyambut program internet gratis dari pemerintah kota Surabaya. Program tersebut dicoba diimprovisasi yang kemudian melahirkan kampung siber. Sebuah program yang tidak sekedar menjadikan fasilitas internet sebagai media informasi semata, tetapi sebagai instrument penggerak partisipasi warga, penumbuh kepercayaan warga, dan media pembentuk persepsi positif tentang kampung Jojoran (image positif).

Ketika kampung siber dikreasi secara asumtif warga Jojoran sadar bahwa teknologi (internet) merupakan media efektif dalam 'menyapa' warga kampung. Apalagi saat ini sebagian besar warga kampung telah melek teknologi (internet). Melalui program itu warga akan tahu banyak hal tentang dinamika kampungnya. Bersaling sapa secara virtual, bertkuar informasi tentang banyak hal dan menggalang partisipasi antarwarga. Pendek kata dinamika warga kampung 
mulai beranjak di dunia virtual. Sebuah dinamika yang memberikan "kebebasan" kepada warga untuk berpartisipasi kapanpun tanpa terikat ruang dan waktu. Dalam ari ketika warga disibukkan dengan aktifitas kerja, dan memanfaatkan waktu luangnya untuk istirahat namun di sela-sela itu mereka masih mau "bercengkrama" secara virtual membincang keadaan kampung. Dengan demikian tanpa disadari, program kampung siber telah menjadi instrument pendorong dinamika warga Jojoran 3B.

Dalam perspektif Marshal McLuhan ${ }^{347}$ realitas kampung siber Jojoran 3B merupakan "penjelasan riil" dari beroperasinya teori ekologi media di masyarakat Ketika masyarakat teknologi media telah melingkupi aktifitas manusia, maka semua hal yang menyakut pola pikir dan tindakan manusia dipengaruhi oleh teknologi media. Dalam kondisi itu menjadikan dan memanfaatkan teknologi media (internet) untuk kepentingan menggerakkan warga kampung akan menjadi lebih efektif terumasuk mengubah persepsi warga tentang kampungnya sendiri serta mengorganisasikan berbagai pengalaman warga dalam media tersebut. Sebuah langkah kreatif pengurus RT dalam mendinamisasikan warga.

\section{Memahami konstruksi sosial keluarga muslim di Jojoran 3B}

Domestikasi teknologi informasi dan komunikasi tidak dapat dilepaskan dari proses konstruksi yang dilakukan keluarga muslim. Sebuah proses yang melibatkan dua elemen keluarga yaitu anak muda (digital native) dan orang tua (digital Immigrant). Sebagai anak yang dilahirkan dalam suasana dan berseiringan dengan perkembangan teknologi hamper dapat dipastikan mengalami kemudahan dalam mengadaptasi perkembangan teknologi. Teknologi telah menjadi "teman" keseharian anak muda. Bahkan kali pertama dia "mengenal dunia", teknologi telah menyapanya, tentunya ini tidak terlepas dari peran orang tua. Karena itu, apapun yang menyangkut teknologi anak muda merasa lebh cepat belajar dan beradaptasi dengan teknologi. Berbeda dengan orang tua, jika kelahirannya berada dalam "ruang yang sama" dengan perkembangan teknologi sebagai mana anaknya, maka posisinya akan hampir sama. Tetapi ketika posisinya cukup jauh dari dengan "sentuhan" dengan teknologi, maka perlu usaha untuk melakukan penyesuaian. Ketika teknologi hadir dalam ruang keluarga, maka yang muncul adalah dinamika penyikapan yang berujung pada dialektika antara anak, orang tua dengan keberadaan teknologi.

Proses dialektika dimaksud merupakan tahap konstruksi yang dilakukan keluarga dalam mendomestikasi teknologi informasi dan komunikasi, dalam perspektif teori kontruksi sosial melibatkan tiga momen yaitu ekternalisasi, obyektifasi dan internalisasi.

\section{a. Ekternalisasi}

Eksternalisasi merupakan usaha pencurahan atau ekspresi diri manusia ke dalam dunia, baik dalam kegiatan mental maupun fisik. Proses ini merupakan bentuk ekspresi diri untuk menguatkan eksistensi individu dalam masyarakat. Proses ini menurut Handyani 348 dialami ketika produk sosial yang tercipta pada kehidupan masyarakat, kemudian individu beradaptasi dengan kondisi sosialnya agar menjadi bagian dari masyarakat tersebut. Proses dinamika sosial masyarakat merupakan produk manusia yang terus menerus diproduksi melalui tindakan sehari-hari.

\footnotetext{
347 Dalam teori ekologi media, Marshal McLuhan menyatakan bahwa pengaruh teknologi media terhadap masyarakat begitu signifikan. Apalagi dalam dinamika saat ini, sulit bagi masyarakat meninggalkan dan mengabaikan keberadaan teknologi media. Keberadaannya sangat vital dan menempati posisi penting dalam kehidupan masyarakt. Karena itu perbaikan persepsi khalayak melalui dan difasilitasi teknologi media dipandang lebih efektif. Teori ekologi media dibingkai oleh asumsi sebagai berikut: (a) Media melingkupi setiap tindakan di dalam masyarakat, (b) media memperbaiki persepsi kita dan mengorganisasikan pengalaman kita, (3) media menyatukan seluruh dunia. Lihat Richard West dan Lyn H Turner. Teori Komunikasi: Analisis dan Aplikasi. Terj. Maria Natalia (Jakarta: Salemba Humanika, 2007), h. $140-142$.

348 Natalia Indah Handayani, "Realitas Kampung Cyber: Studi Fenomenologi Terhadap Masyarakat Kampung RT.36, Taman, Patehan, Yogyakarta" dalam Jurnal Universitas Airlangga.www.Journal.unair.ac.id
} 
Sementara menurut Nursyam, ${ }^{349}$ eksternalisasi merupakan proses momen adaptasi diri dengan dunia sosio kultural, melalui media bahasa dan tindakan. Karena itu proses adaptasi yang dilakukan akan selalu menggunakan bahasa dan tindakannya. Konsekuensinya proses adaptasi tersebut akan menghasilkan penerimaan dan penolakan. Penerimaan akan berujung pada kemampuan adaptasi dari diri dengan realitas sosialnya, sementara penolakan akan berujung pada keengganan untuk beradaptasi dengan realitas sosialnya.

Dalam konteks keluarga muslim di Jojoran 3B, proses ekternalisasi dapat dijabarkan sebagai berikut:

Pertama, proses adaptasi keluarga muslim dengan piranti teknologi informasi dan komunikasi. Proses ini menyangkut bagaimana mulai mengenal, menggunakan dan memanfaatkan teknologi dalam kehidupan sehari-hari. Pada tahap pengenalan, ada upaya untuk mengerti seperti apa dan untuk apa teknologi itu. Pada tahap menggunakan upaya mengarah pada cara yang dilakukan dalam mengoperasikannya, sementara tahap memanfaatkan merupakan pemahaman yang lebih baik tentang manfaat dan kegunaan ketika memiliki dan menggunakan teknologi bagi kehidupan personal dan keluarga.

Ketika proses adaptasi terhadap perangkat teknologi informasi dan komunikasi dilakukan seperti itu, tampak bahwa keluarga muslim di Jojoran 3B melakukannya secara apropriatif. Sebuah tindakan adaptasi yang dilakukan dengan cara memilah dan memilih, menggolah dan memanfaatkan berdasarkan pertimbangan dan interpretasinya terhadap piranti itu. Proses apropriatif itu diiringi oleh sikap dan tindakan reseptif, kritis, transformatif dan kreatif,

Pada proses reseptif, tindakan ini dihasilkan dari mindset keluarga muslim dalam memahami keberadaan teknologi informasi dan komunikasi, yang tidak sekedar mengenal, menggunakan namun telah memanfaatkannya, minimal untuk memenuhi kebutuhan diri keluarga muslim tersebut. Tindakan-tindakan yang diambil oleh keluarga ini menghasilkan sikap dan tindakan reseptif. Sikap dan tindakan menerima kehadiran teknologi informasi dan komunikasi dalam lingkungan keluarga karena kebermanfaatannya.

Pada proses kritis, keluarga muslim yang pada awalnya menerima kehadiran teknologi informasi dan komunikasi begitu saja mulai mempertanyakan kehadirannya. Seiring dengan informasi yang diterima personal keluarga terhadap kemenduaan sifat teknologi. Satu sisi memberikan dampak positif di sisi lain memiliki dampak negatif. Kemenduaan inilah menjadikan sikap kritis anggota keluarga menghasilkan proses negosiasi antara orang tua (digital immigrant) dan anak (digital native). Bagi kelompok orang tua, kehadiran teknologi meski diterima, namun penerimaannya harus didasari kehati-hatian. Tidak sekedar menggunakan dan memanfaatkannya saja, mengingat tidak ada jaminan bahwa teknologi itu selalu memberikan dampak positif bagi penggunanya, misalnya kecanduan dan menyalahgunakan piranti itu untuk tindakan tidak terpuji. Sementara bagi kelompok anak (muda) menyikapi keberadaan teknologi sebagai kebutuhan pokok saat ini. Sebagai media eksploratif dalam menggali berbagai informasi, dan sebagai media artikulasi identitas mereka sebagai anak muda di era digital.

Pada proses transformatif yang tampak adalah upaya personal keluarga muslim saling menransformasikan pengetahuannya terkait dengan pemahaman mereka terhadap teknologi informasi dan komunikasi. Sebenarnya proses ini merupakan kelanjutan proses negosiasi. Konsekuensinya masing-masing pihak berusaha meyakinkan argumentasi berdasarkan pemahamannya. Upaya saling tranfer pengetahuan ini menjadikan kedua belah pihak (digital immigran dan native) berusaha membangun pemahaman yang berujung pada kesepakatan, kesalingmengertian bagaimana memposisikan teknologi informasi dan komunikasi dalam kehidupan keluarga. Dalam level yang lebih besar, ternyata proses ini berlangsung pada keluarga muslim lain, sehingga tanpa disadari proses transformasi pengetahuan telah menghasilkan kesalingmengertian antarkeluarga muslim di wilayah Jojoran.

${ }^{349}$ Nurysam. Islam Pesisir. (Yogyakarta: LkiS, 2005), h.249 
Terakhir dari langkah apropriasi warga adalah proses kreatif. Proses ini lahir dari kepekaan dalam menghadapi teknologi informasi dan komunikasi yang tidak sekedar digunakan sebagai pendamping keluarga, tapi sebagai media informatif dan kreatifitas. Pada moment inilah lahir program kampung siber yang digagas oleh anak muda Jojoran 3B ketika dihadapkan pada program internet gratis dari pemerintah kota Surabaya. Melalui program kampung siber ini, warga dan keluarga muslim di Jojoran menyaksikan sendiri bahwa teknologi informasi dan komunikasi dapat dimanfaatkan untuk kepentingan kampung, mendinamisasi warga kampung bahkan mampu memperbaiki citra kampung Jojoran yang selama ini dikesankan sebagai kampung preman di Surabaya.

Dengan berbagai proses adaptasi itu, tampak eksternalisasi yang dilakukan keluarga muslim Jojoran 3B menemukan momentumnya ketika program kampung siber diluncurkan, yang secara tidak langsung memberikan efek pada penerimaan dan pengadaptasian terhadap perangkat teknologi informasi dan komunikasi pada lingkungan kampung dan keluarga.

Kedua, penyesuaian dengan nilai-nilai tradisi yang terkait dengan keberadaan teknologi informasi dan komunikasi. Proses ini sebenarnya dapat dibaca sebagai upaya membaca keberadaan teknologi informasi dan komunikasi yang hadir dalam lingkungan secara kultural. Maksudnya proses adaptasi itu melibatkan sisi nilai yang dianut oleh masing-masing keluarga muslim, nilainilai keislaman.

Sebagai keluarga muslim, tentunya nilai-nilai keislaman menjadi pertimbangan utama dalam menyikapi setiap perubahan yang terjadi di masyarakat, termasuk dalam hal ini keberadaan teknologi informasi dan komunikasi. Beragamanya pemahaman terhadap nilai-nilai keislaman yang dimiliki keluarga muslim di Jojoran 3B, dalam arti tingkat pemahaman keislamannya cukup variatif menjadikan seorang tokoh agama sebagai rujukan referensi pertimbangan, termasuk juga menjadikan personal warga Jojoran yang mengerti teknologi. Berbekal referensi rujukan itulah, muncul dua penyikapan keluarga muslim terhadap keberadaan teknologi informasi dan komunikasi, yaitu penerimaan dan penolakan. Bagi yang menerima keberadan piranti itu akan menghasilkan dan mewujud dalam tindakan partisipatif. Artinya keluarga muslim yang menerima, tidak sekedar menggunakan dan memanfaatkan teknologi namun mereka juga ikut berpartisipasi dalam program kampung siber. Banyaknya keluarga muslim yang terlibat dalam menyukseskan program kampung siber mengindikasikan penerimaan betapa mereka menerima kehadiran teknologi informasi dan komunikasi, berikut konsekuensi kulturalnya. Dalam arti penerimaan terhadap piranti itu telah melahirkan tradisi baru dalam keluarga muslim dan kampung Jojoran 3B.

Namun demikian, ada juga sebagian keluarga muslim dan warga di kampung Jojoran yang menolak terhadap hadirnya teknologi informasi dan komunikasi dalam lingkungan keluarga dan kampung. Penolakan itu tentunya berbasis referensi dan argumentasi yang mereka miliki. Sebagai bentuk kongkrit dari penolakan itu adalah mereka tidak mau menggunakan perangkat teknologi itu terutama internet. Mereka yang menolak selalu mengontruksi secara bahasa dan tindakan dengan menyatakan bahwa teknologi itu lebih banyak memberikan kemudharatan bagi kehidupan keluarga muslim, terutama pada anak-anak mereka. Bahkan keberadaan program kampung siber dipandang sebagai pemicu anak-anak mereka menjadi keranjingan teknologi (internet), dan menjadi penyebab kelalaian dalam menjalankan kewajibannya sebagai anak, pelajar dan umat beragama.

\section{b. Obyektifikasi}

Obyektifikasi sebagai kelanjutan dan tahap ekternalisasi merupakan tahap perlakuan keluarga muslim terhadap teknologi informasi dan komunikasi. Keberadaan teknologi ini telah menjadi realitas objektif, yang seolah-olah berada di luar diri manusia (keluarga muslim). Objektifasi oleh Berger dan Luckman dalam Bungin ${ }^{350}$ dinyatakan sebagai produk sosial yang terjadi dalam realitas intersubyektif masyarakat yang dilembagakan, individu untuk memanifestasikan dirinya ke dalam produk sosial yang telah diciptakan masyarakat.

350 Burhan Bungin. Konstruksi Sosial Media Massa. (Jakarta: Kencana Media, 2008), h.16 
Dengan posisi ini, seakan-akan terkonstruksi dua realitas, yaitu realitas teknologi informasi dan komunikasi yang bersifat objektif, dan realitas kehidupan keluarga muslim yang bersifat subyektif. Dua realitas inilah yang dalam "perjalanannya" saling berinteraksi dan berkelindan melalui proses pelembagaan (institusionalisasi) dan pembiasaan (habitualisasi). Kedua proses berlangsung dan diproduksi berulang-ulang sehingga terjadi pengendapan dan tradisi, yang pada akhirnya tersimpan dan membentuk kesadaran yang mentradisi dan ditradisikan.

Pertama, proses institusionalisasi atau pelembagaan merupakan proses membangun kesadaran menjadi tindakan. Dalam proses pelembagaan nilai-nilai yang dijadikan pedoman bagi keluarga muslim di wilayah Jojoran 3B diinterpretasi sehingga menjadi tindakan yang bertujuan. Artinya domestikasi yang dilakukan keluarga muslim didasari nalar kesadaran, untuk apa teknologi informasi dan komunikasi bagi keluarganya.

Berangkat dari nalar kesadaran itulah mulai dikonstruksi berbagai "citra" teknologi bagi keluarga muslim. Mulai dari keberadaannya yang dapat memberikan kemudahan bagi pekerjaan, memiliki dampak positif meski tidak menafikan dampak negatifnya, menambah jaringan interaksi yang tidak sekedar memperluas pertemanan, menambah pengetahuan serta meningkat citra positif keluarga muslim dan kampungnya. Melalui konstruksi nalar kesadaran tersebut sejatinya keluarga muslim mengetahui arti penting dan manfaat keberadaan teknologi informasi dan komunikasi bagi diri dan keluarganya. Proses ini juga menemukan momen ketika program kampung siber berdiri dan berjalan. Seolah menjadi peneguh program kampung siber merupakan wujud betapa manfaatnya kehadiran teknologi informasi dan komunikasi bagi keluarga dan warga kampung Jojoran 3B. Ini bukan berarti proses pelembagaan mementingnya hadirnya lembaga secara struktural, tetapi bagaimana pola pikir dan pola tindak keluarga muslim dalam menerima, menggunakan dan memanfaatkan teknologi informasi dan komunikasi semakin mengakar dalam kehidupan. Dengan demikian, proses pelembagaan tersebut tindakan keluarga muslim dalam mendomestikas teknologi informasi dan komunikasi didasarkan pada perhitungan yang matang, sehingga tindakan yang dilakukan menjadi tindakan rasional yang bertujuan.

Kedua, proses pembiasaan (habitualisasi). Proses ini merupakan tindakan rasional bertujuan itu telah menjadi bagian dari kehidupan sehari-hari. ${ }^{351}$ Tidak diperlukan pertimbangan dan interpretasi terhadap tindakan yang dilakukannya, karena semuanya telah diperhitungkan dan dipertimbangkan sebelumnya. Dalam konteks ini semua tindakan yang dilakukan keluarga muslim dalam menggunakan dan memanfaatkan teknologi informasi dan komunikasi telah menjadi tindakan yang secara mekanis berlangsung begitu saja. Dalam arti semua seolah-olah otamatis, telah menyatu dalam sistem kognisi dan evaluasi manusia. Ketika manusia melakukan aktifitasnya ketika itupula peranti itu selalu menemani atau sebaliknya semua tindakan yang dilakukan manusia selalu menggunakan dan memanfaatkan piranti teknologi itu sebagai instrumen penunjangnya.

Dalam konteks domestikasi, proses pembiasaan (habitualisasi) ini berada dalam ranah proses inkorporasi. Sebuah proses yang menjadikan teknologi informasi dan komunikasi telah menjadi satu kesatuan dalam irama kehidupan keluarga muslim. Misalnya untuk keperluan berinteraksi seseorang akan selalu menggunakan telepon genggam, ataupu membuka-buka media sosialnya untuk mengetahui perkembangan pertemanannnya. Untuk mengetahui informasi seseorang akan segera menghidupkan televisi atau membuka internet yang berisi situs-situs pemberitaan. Tindakan ini disadari dan berlangsung secara mekanis, dan ini dilakukan berulang-ulang hingga menjadi sebuah kebiasaan (habituasi) bagi seseorang termasuk keluarga muslim di wilayah Jojoran 3B.

351 Nursyam. Islam Pesisir..., h.254 


\section{c. Internalisasi}

Proses berikutnya dari beroperasi teori konstruksi sosial dalam proses domestikasi informasi dan komunikasi keluarga muslim di wilayah Jojoran 3B adalah proses internalisasi. Secara etimologis, internalisasi merupakan penghayatan terhadap suatu ajaran, doktrin atau nilai sehingga menjadi keyakinan dan kesadaran seseorang terhadap kebenaran ajaran atau nilai yang kemudian mewujud dalam sikap dan tindakan ${ }^{352}$.

Sikap dan tindikan individu yang mewujud tersebut akan mengidentifikasi diri di dalam dunia sosio kulturalnya. Hal ini lebih disebabkan proses internalisasi merupakan momen penarikan realitas sosial ke dalam diri atau realitas sosial menjadi kenyataan subyektif. ${ }^{353}$ Oleh karena individu atau keluarga muslim yang telah mendomestikasi teknologi informasi dan komunikasi akan mengidentifikasi diri sebagai bagian dari warga melek teknologi. Artinya ada kecenderungan individu-individu dalam keluarga muslim itu akan selalu mengelompok dengan individu-individu yang dipandang memiliki pola pikir yang sama. Tak heran, ketika kampung siber dicanangkan cukup banyak individu dan keluarga muslim yang mengelompokkan diri dalam akun media sosial milik warga kampung Jojoran 3B.

Pengelompokan ini bukan bermakna pemisahan warga. Namun pengelompokan ini lebih didasarkan pada pemahaman betapa penting dan bermanfaatnya keberadaan teknologi informasi dan komunikasi bagi personal, keluarga dan warga kampung di Jojoran 3B. Melalui pengelompokan ini warga dan keluarga muslim melakukan penguatan mental, membangun pengetahuan, kesadaran dan keterampilan dalam menggunakan dan memanfaatkan teknologi informasi dan komunikasi bagi kehidupan keluarganya. Pada konteks yang lebih luas pengelompokan ini menjadi media bagaimana keluarga muslim mewariskan pengetahuan dan keterampilannya pada generasi berikutnya terkait dengan keberadaan teknologi informasi dan komunikasi.

\section{Tabel 1. Dialektika eksternalisasi, obyektifasi dan internalisasi keluarga muslim dalam mendomestikasi teknologi informasi dan komunikasi}

\begin{tabular}{|c|c|c|}
\hline Momen & Proses & Penjelasan \\
\hline Eksternalisasi & $\begin{array}{l}\text { Penyesuian diri } \\
\text { dengan realitas" } \\
\text { teknologi informasi } \\
\text { dan komunikasi }\end{array}$ & $\begin{array}{l}\text { Menyesuaikan dengan piranti teknologi informasi dan } \\
\text { komunikasi sesuai dengan pemahaman mereka, } \\
\text { bahwa semua tindakan mereka dalam mengenal, } \\
\text { menggunakan dan memanfaatkan teknologi informasi } \\
\text { dan komunikasi memiliki basis rasionalitas, dan nilai- } \\
\text { nilai yang dianut. } \\
\text { Menyesuaikan "cara kerja" pengenalan, penggunaan } \\
\text { dan pemanfaatan sebagaimana pemahaman dan } \\
\text { referensi yang mereka dapatkan. }\end{array}$ \\
\hline Obyektifikasi & $\begin{array}{l}\text { Interaksi diri dengan } \\
\text { realitas" teknologi } \\
\text { informasi dan } \\
\text { komunikasi }\end{array}$ & $\begin{array}{l}\text { Melakukan proses pelembagaan tindakan mengenal, } \\
\text { menggunakan dan memanfaatkan teknologi informasi } \\
\text { dan komunikasi sebagai tindakan yang bertujuan. } \\
\text { Tindakan yang didasari oleh nalar kesadaran tentang } \\
\text { makna dan fungsi teknologi itu. Tindakan bertujuan } \\
\text { itu terus direproduksi dan diulang hingga menjadi } \\
\text { habitus yang secara mekanis bersifat otomatis, yang } \\
\text { pada ujungnya menghasilkan inkorporasi. Yaitu } \\
\text { menjadikan teknologi informasi dan komunikasi } \\
\text { menjadi satu kesatuan dalam irama kehidupan } \\
\text { keluarga muslim. }\end{array}$ \\
\hline
\end{tabular}

352 Kamus Besar Bahasa Indonesia. http://kbbi.web.id diakses tanggal 29 Agustus 2016

353 Nursyam, Islam Pesisir...., h. 255 


\begin{tabular}{|l|l|l|}
\hline \multicolumn{1}{|c|}{ Momen } & \multicolumn{1}{|c|}{ Proses } & \multicolumn{1}{c|}{ Penjelasan } \\
\hline Internalisasi & Identifikasi diri & Adanya pengelompokan warga yang berbasis \\
& dengan "realitas" & pemahaman dan kepengertian seseorang dan \\
& teknologi informasi & keluarga muslim dalam menyikapi keberadaan \\
& dan komunikasi & teknologi informasi dan komunikasi bagi kehidupan \\
& & keluarga, serta menciptakan mekanisme alamiah \\
& & dalam mewariskan dan menradisikan sikap dan \\
& & tindakan dalam menghadapi perubahan sebagai \\
& & dampak hadirnya teknologi informasi dan \\
& & komunikasi \\
\hline
\end{tabular}

\section{Simpulan}

Berdasarkan kajian ini, kiranya dapat ditarik kesimpulan sebagai berikut:

Pertama, keluarga muslim di wilayah Jojoran 3B RT.12 RW. XIII melakukan domestikasi terhadap teknologi informasi dan komunikasi bertumpu pada nilai dan interpretasinya yang ditopang oleh nalar kesadaran, sehingga menjadikan proses domestikasi teknologi informasi dan komunikasi sebagai tindakan yang bertujuan. Tindakan yang didasari oleh kesadaran dan argumentasi terhadap makna, fungsi dan urgensi teknologi informasi dan komunikasi bagi dinamika kehidupan keluarga muslim di wilayah Jojoran 3B.

Kedua, proses domestikasi yang dilakukan oleh keluarga muslim tertopang oleh keberadaan program kampung siber yang mampu mempertemukan orang tua (digital immigrant) dan anak muda (digital native) dalam sebuah negosiasi budaya yang melahirkan proses appropriasi, obyektifikasi, inkorporasi dan konversi dalam mendorong proses domestikasi teknologi informasi dan komunikasi lebih cepat.

Ketiga, proses domestikasi teknologi informasi dan komunikasi disadari memberikan dampak positif dan negatif terhadap kehidupan keluarga muslim di Jojoran 3B, terutama dari sisi keberagamaan dan interaksi sosial keluarga muslim dengan warga sekitarnya. Meski demikian, dampak itu disadari sebagai konsekuensi logis dari sikap dan tindakan yang telah diputuskan bersama antara orang tua (digital immigrant) dan anak muda (digital native). Melalui upaya mengelompokkan diri dalam "gerbong" kampung siber, personal dan keluarga muslim mengonstruksi nalar kesadaran dan mewariskannya pada generasi berikut dalam menghadapi perubahan-perubahan yang diakibatkan oleh keberadaan teknologi informasi dan komunikasi.

\section{Daftar Pustaka}

Arif, Moch. Choirul. 2016. "Media dan Teknologi Informasi dan Komunikasi" materi kuliah pascasarja S2 program Studi Komunikasi dan Penyiaran Islam IAIN Jember

Berger, Peter L dan Luckman, Thomas. 1990. Konstruksi Sosial atas Realitas. Jakarta: LP3ES

CNN Indonesia, “2014, Pengguna Internet Indonesia capai 88, 1 juta” Kamis/26/2015 (online) www.cnnindonesia.com diakses tanggal 1 maret 2016

Faoziyah, NM. 2013. "Pemberdayaan Masyarakat Berbasis Teknologi Informasi: Studi di Kampung Siber" Skripsi UIN Sunan Kalijaga Yogyakarta.

Green, Lelia 2001. Communikcation, Technology and Society. London: Sage Publication.

Handayani, Natalia Indah, "Realitas Kampung Siber: Studi Fenomenologi Terhadap Masyarakat Kampung RT.36 Taman Patehan Yogyakarta" journal.unair.ac.id/download-fullpapers$\ln 30505$ dd856full.pdf

Hubberman, A. Michael Matthew dan B, 1992. Miles. Analisis Data Kualitatif. Terj. Tjejep.Jakarta: UI Press. 
Jamilah. 2014 Teknologi Informasi dan Perubahan Sosial Keagamaan: Studi di Kampung Siber RT.36 RW.09 Taman Patehan Kraton Yogyakarta. Skripsi Jurusan Sosiologi Agama Fakultas Ushuludddin dan Pemikiran Islam Universitas Islam Negeri Sunan Kajijaga, Yogyakarta.

Kamus Besar Bahasa Indonesia versi online / dalam jaringan

Lestari, Sri 2012. Psikologi Keluarga: Penanaman Nilai dan Penanganan Konflik dalam Keluarga Jakarta: Prenada Media Group.

Natalia Indah Handayani, "Realitas Kampung Siber: Studi Fenomenologi Terhadap Masyarakat Kampung RT.36, Taman, Patehan, Yogyakarta” dalam Jurnal Universitas

Airlangga.www.Journal.unair.ac.id

Nursyam. 2005. Islam Pesisir Yogyakarta; LkiS.

Prasetyo, Antonius Galih, 2013 “Domestikasi Teknologi Internet: Studi di Kampoeng Siber RT. 36 Taman Yogyakarta. Tesis Universitas Gadjah Mada Yogyakarta.\

Purbawaningsih, Yudi. Arifin, Pupung dan Wulandari, Theresea D. 2013. "Pergeseran Pola Komunikasi Antarpersonal Warga Kampung Pasca Pemasangan Jaringan Internet" Riset Fakultas Ilmu Sosial dan Ilmu Politik Universitas Atmadjaya Yogyakarta.

Rusdi, Farid. Paramita, Sinta dan Sanjaya, Wulan Purnama. 2015. "Analisis Penggunaan New Media oleh Pelaku UKM di Kampung Siber" Riset Fakultas Ilmu Komunikasi Universitas Taruma Negara.

Richard West dan Lyn H Turner. 2007.Teori Komunikasi: Analisis dan Aplikasi. Terj. Maria Natalia Jakarta: Salemba Humanika.

Yudaninggar, Kartikasari. 2013. "Internet dan Perubahan Sosial: Studi Peran Internet Sebagai Alat Perubahan Sosial Pada Masyarakat Kampung Siber di RT.36 Patehan Yogyakarta". Skripsi Fakultas Ilmu Komunikasi Universitas Sebelas Maret Surakarta,

Yeni. R. 2012 "Pola Interaksi Masyarakat di Kampung Siber RT.36 Taman Patehan Yogyakarta” Skripsi Universitas Negeri Yogyakarta 